\title{
FLOWERING AND YIELD CHARACTERISTICS OF MACAPUNO-BEARING DWARF X TALL COCONUT HYBRIDS
}

by

\author{
T. C. Nunez and V. M. de Paz ${ }^{1}$
}

\begin{abstract}
Three macapuno-bearing dwarf $\mathrm{x}$ tall coconut hybrid trees were observed to exhibit some characteristics influenced by the dwarf female parents. Flowering started as early as 39 to 57 months after planting. Intraspadix overlapping of 43 to $100 \%$ was also recorded suggesting moderate to high degree of self pollination.
\end{abstract}

Macapuno yield ranged from $0-50 \%$ per bunch. The nuts resemble the female parents in form but were generally heavier. They were all classified as type 1 macapuno.

Binomial test showed goodness of fit to 3:1 ratio of normal to macapuno nuts.

\section{INTRODUCTION}

Macapuno, an aberrant form of coconut, is one of the highly priced agricultural crops in the Philippines particularly in Luzon which is the biggest island in the country. It is considered as a delicacy whose price may range from 10 or more times higher than that of the ordinary nut. The soft glutinous meat that almost fill the cavity of a mature nut is often consumed as sweetened or used as flavoring for ice cream, candies and pastries. Naturally occurring macapuno-bearing trees are tall, rare and bear only about 3-18\% aberrant nuts being heterozygous for the character. No homozygous macapuno trees were found in the country until Dr. de Guzman of U.P. at Los Banos successfully grew homozygous macapuno embryos into fully developed trees which can give as high as $100 \%$ macapuno yield when grown in isolation. These in vitro cultured trees are cross pollinated. Actual observations showed very little degree of intraspadix overlapping while in some inflorescences the male phase had totally ended even before the female phase started. Thus, they are dependent to a considerable degree on pollen from other trees for pollination, making them vulnerable to unwanted pollination which reduces the yield of pure macapuno trees as fertilization with normal pollen produces normal nuts (PCRDF,1985). Like most talls, the in vitro cultured macapuno, flowers at 5-7 years after field planting or about 7-9 years from planting the embryo in culture medium.

So far, no other type of macapuno-bearing populations were reported in literature aside from the talls. In ViSCA, Baybay, Leyte, Philippines three macapuno-bearing dwarf x tall (D x T) coconut trees which are part of an ongoing study aiming to develop improved macapuno genotypes were observed. Their characteristics and potential are herein discussed.

\section{MATERIALS AND METHODS}

Three seven year old macapuno-bearing D x T coconut trees were studied in 1987-1988 for their flowering characteristics and aberrant nut yield. These hybrid trees are two Malayan Yellow Dwarf (MYD) x Macapuno (MAQ and one Malayan Red Dwarf (MRD) x MAC.

\footnotetext{
${ }^{1}$ Science Research Specialist and Research Assistant, respectively, Regional Coconut Research Center, Visayas State College of Agriculture, Baybay, Leyte, Philippines.
} 


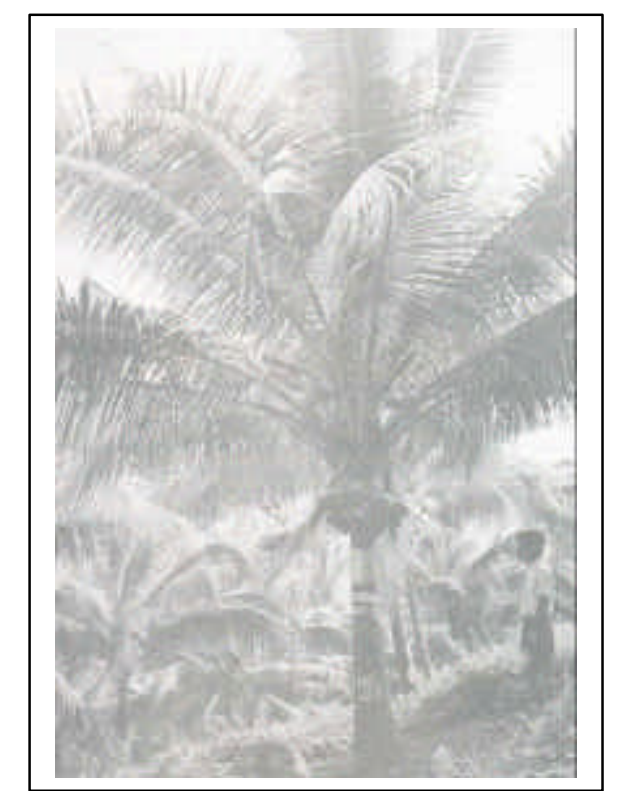

Fig. 1. An eight year old macapuno-bearing D x T hybrid showing typical

Morphological characteristics

Each newly opened inflorescence was observed for the duration of its male and female phase and the period of their overlapping. Intraspadix overlapping was expressed as the percentage of the female phase of an inflorescence which was covered by its male phase.

Data on yield and macapuno nut characteristics were gathered as soon as browning of nuts started in a bunch indicating maturity.

Each macapuno nut was classified following the system adopted by Adriano and Manahan (1931) who described three types of macapuno with the following characteristics:

a. Type I - consists of three layers; a semi-liquid layer, a soft viscous layer and a layer next to the shell with the consistency of hard boiled rice.

b. Type II - consists of two layers; a soft viscous layer and a layer next to the shell with the consistency of hard boiled rice.

c. Type III - consists wholly of a layer with the consistency of hard boiled rice filling the whole cavity.

\section{RESULTS AND DISCUSSION}

\section{Flowering Behavior}

The macapuno-bearing D x T hybrids exhibiting the typical morphology and growth of such type of hybrids (Fig. 1) started to, flower at 39-57 months after field planting. MRD x MAC \#66 flowered the earliest while MYD x MAC \#52 had the latest initial flowering among the three.

Some differences in their floral characteristics were also observed. They varied in mean button count per inflorescence with MYD x MAC \#61 having the highest and MYD x MAC \#52 the lowest (Table 1). However, the mean duration of their pollen shedding and stigmatic receptivity did not show much difference. Among the parameters studied, duration of the male phase was the least 
variable while number of buttons per inflorescence was the most variable. Intraspadix overlapping appeared to be quite stable.

Table 1. Flowering characteristics of three macapuno-bearing D x T hybrids

\begin{tabular}{|c|c|c|c|c|c|}
\hline Cross & $\begin{array}{c}\text { Inflorescence } \\
\text { Number }\end{array}$ & $\begin{array}{l}\text { Number of } \\
\text { Buttons }\end{array}$ & $\begin{array}{c}\text { Pollen } \\
\text { Shedding } \\
\text { (days) }\end{array}$ & $\begin{array}{l}\text { Stigmatic } \\
\text { Receptivity } \\
\text { (days) }\end{array}$ & $\begin{array}{c}\text { Intraspadix } \\
\text { Overlapping } \\
(\%)\end{array}$ \\
\hline $\begin{array}{c}\text { MYD x MAC } \\
\quad \# 52\end{array}$ & $\begin{array}{l}1 \\
2 \\
3 \\
4 \\
5 \\
6 \\
7 \\
8\end{array}$ & $\begin{array}{c}5 \\
9 \\
16 \\
19 \\
15 \\
15 \\
14 \\
12\end{array}$ & $\begin{array}{l}20 \\
20 \\
20 \\
21 \\
25 \\
18 \\
24 \\
21\end{array}$ & $\begin{array}{c}7 \\
7 \\
6 \\
8 \\
7 \\
10 \\
9 \\
13\end{array}$ & $\begin{array}{c}86 \\
57 \\
67 \\
100 \\
78 \\
100 \\
78 \\
92\end{array}$ \\
\hline & $\begin{array}{l}\text { Mean } \\
\text { C.V. }(\%)\end{array}$ & $\begin{array}{c}13 \\
33.8 \\
\end{array}$ & $\begin{array}{c}21 \\
10.9 \\
\end{array}$ & $\begin{array}{c}8 \\
28.3 \\
\end{array}$ & $\begin{array}{c}82 \\
18.7 \\
\end{array}$ \\
\hline $\begin{array}{c}\text { MYD x MAC } \\
\quad \# 61\end{array}$ & $\begin{array}{c}1 \\
2 \\
3 \\
4 \\
5 \\
6 \\
7 \\
8 \\
9 \\
10 \\
11\end{array}$ & $\begin{array}{l}21 \\
19 \\
20 \\
15 \\
13 \\
26 \\
34 \\
48 \\
37 \\
45 \\
38\end{array}$ & $\begin{array}{l}20 \\
19 \\
21 \\
14 \\
20 \\
22 \\
21 \\
19 \\
16 \\
21 \\
18\end{array}$ & $\begin{array}{c}8 \\
7 \\
7 \\
10 \\
11 \\
8 \\
8 \\
11 \\
10 \\
11 \\
7\end{array}$ & $\begin{array}{c}88 \\
71 \\
71 \\
60 \\
82 \\
87 \\
100 \\
72 \\
70 \\
54 \\
43\end{array}$ \\
\hline & $\begin{array}{l}\text { Mean } \\
\text { C.V. }(\%)\end{array}$ & $\begin{array}{c}28 \\
43.6 \\
\end{array}$ & $\begin{array}{c}19 \\
12.6 \\
\end{array}$ & $\begin{array}{c}9 \\
18.9 \\
\end{array}$ & $\begin{array}{c}72 \\
22.7 \\
\end{array}$ \\
\hline $\begin{array}{c}\text { MYD x MAC } \\
\# 66\end{array}$ & $\begin{array}{l}1 \\
2 \\
3 \\
4 \\
5 \\
6 \\
7 \\
8\end{array}$ & $\begin{array}{c}6 \\
11 \\
15 \\
28 \\
27 \\
25 \\
25 \\
23\end{array}$ & $\begin{array}{l}16 \\
21 \\
21 \\
12 \\
18 \\
20 \\
21 \\
18\end{array}$ & $\begin{array}{c}3 \\
5 \\
6 \\
6 \\
10 \\
7 \\
11 \\
8\end{array}$ & $\begin{array}{c}67 \\
80 \\
83 \\
75 \\
70 \\
100 \\
45 \\
62\end{array}$ \\
\hline & $\begin{array}{l}\text { Mean } \\
\text { C.V. }(\%)\end{array}$ & $\begin{array}{c}20 \\
41.1 \\
\end{array}$ & $\begin{array}{c}18 \\
17.6 \\
\end{array}$ & $\begin{array}{c}7 \\
37.4 \\
\end{array}$ & $\begin{array}{c}73 \\
22.2 \\
\end{array}$ \\
\hline
\end{tabular}

Intraspadix overlapping which may ensure some degree of self pollination was observed to, be moderate to high in the aforesaid D x T hybrids. MYD x MAC \#52 exhibited 57 to $100 \%$ intraspadix overlapping while MYD x MAC \#61 and MRD x \#66 had 43 to 100\% and 45 to 100\%, 
respectively. This manifests the influence of the dwarf parents on the hybrids since intraspadix overlapping in the tall parent is very low if not nil. Moreover, since flowering habit in coconut is markedly affected by the genetic constitution of the tree, there is a good indication that from the cultured macapuno embryos taken from these hybrids. highly self-pollinating and early bearing pure macapuno segregants can be obtained and multiplied for commercial planting.

Occasional cases of intraspadix overlapping were also recorded but emphasis was not given on this since previous observations indicated its less significant role in improving self-pollination (Balingasa, 1975).

\section{Yield}

Table 2 shows the yield of the three macapuno-bearing D x T hybrids. Macapuno yield varied from harvest to harvest and ranged from $0-50 \%$ per bunch. Nevertheless, the means ranging from 16.1 to $27.9 \%$ per bunch can be considered high since the theoretical macapuno yield of a heterozygous tree when selfed is $25 \%$. Moreover, this observation implies too, that selfing is high in the three hybrid trees considering further that each tree was surrounded by normal ones at a planting distance of $8.5 \mathrm{~m}$.

Otherwise at this distance, vulnerability to cross pollination by wind and insects could have reduced the percentage macapuno yield of each tree to a considerable degree. In the case of de Guzman's tall homozygous macapuno trees, cross pollination reduced the yield to $70 \%$ macapuno (PCRDF, 1985). Unwanted pollination in the D x T hybrids however, can not be ruled out especially that insect pollinators were actually observed in the field where the trees are planted.

Results of Binomial test showed goodness of fit of the macapuno yield data for the 3:1 ratio of normal to macapuno nuts suggesting that the aberrant characteristic is controlled by a single hereditary unit.

\section{Nut Characteristics}

All three macapuno-bearing hybrid trees have oblong nuts similar to MRD and MYD, the female parents. Dehusked nuts were almost spherical. Similar to most D x T hybrids, these macapuno nuts were generally heavier and bigger than MRD and MYD nuts. Observations showed that dehusked hybrid macapuno nuts weighed from 575 to $1,320 \mathrm{~g}$ (Table 3).

The hybrid macapuno nuts were all classified as type 1 having three distinct layers of endosperm: a semi liquid layer, a soft viscous layer and a layer with the consistency of hard boiled rice (Fig. 2).

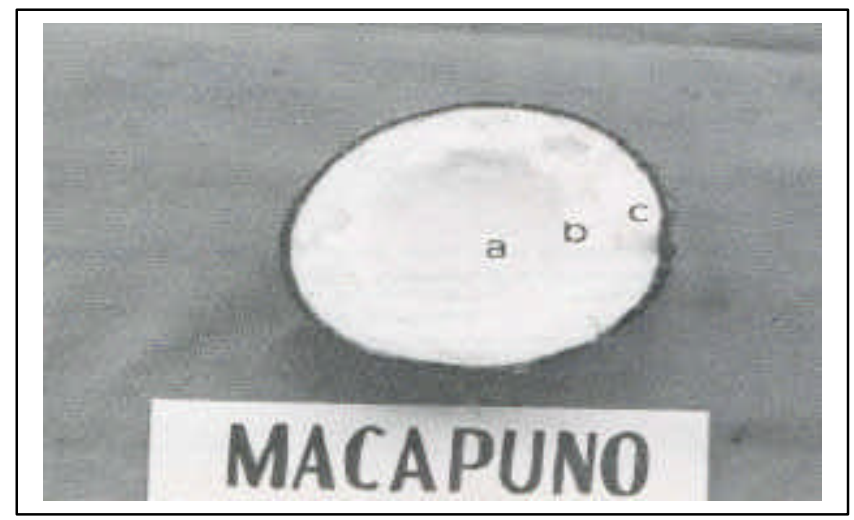

Fig 2. Halved macapuno nut showing three district endosperm layers: a semi-liquid Layer (a); a soft viscous layer (b); and a layer with the consistency of hard-boiled Rice (c). 
Table 2. Macapuno yield of three D x T coconut hybrids

\begin{tabular}{|c|c|c|c|c|}
\hline Cross & $\begin{array}{l}\text { Bunch } \\
\text { Number }\end{array}$ & $\begin{array}{c}\text { Number of nuts } \\
\text { Per bunch }\end{array}$ & $\begin{array}{c}\text { Number of } \\
\text { Macapuno nuts }\end{array}$ & $\begin{array}{c}\text { Percentage } \\
\text { Macapuno yield }\end{array}$ \\
\hline \multirow[t]{2}{*}{$\begin{array}{l}\text { MYD x MAC } \\
(\# 52)\end{array}$} & $\begin{array}{l}1 \\
2 \\
3 \\
4 \\
5 \\
6 \\
7\end{array}$ & $\begin{array}{c}8 \\
2 \\
2 \\
3 \\
2 \\
5 \\
10\end{array}$ & $\begin{array}{l}2 \\
1 \\
0 \\
0 \\
1 \\
2 \\
0\end{array}$ & $\begin{array}{c}25 \\
50 \\
0 \\
0 \\
50 \\
40 \\
0\end{array}$ \\
\hline & \multicolumn{2}{|c|}{$\begin{array}{c}\mathrm{ns} \\
\mathrm{Zc}=0.412\end{array}$} & \multicolumn{2}{|c|}{ Mean $=23.6$} \\
\hline \multirow[t]{2}{*}{$\begin{array}{l}\text { MYD x MAC } \\
(\# 61)\end{array}$} & $\begin{array}{l}1 \\
2 \\
3 \\
4 \\
5 \\
6 \\
7 \\
8 \\
9\end{array}$ & $\begin{array}{l}4 \\
6 \\
5 \\
3 \\
2 \\
3 \\
2 \\
3 \\
1\end{array}$ & $\begin{array}{l}1 \\
1 \\
1 \\
0 \\
0 \\
1 \\
1 \\
0 \\
0\end{array}$ & $\begin{array}{c}25 \\
17 \\
20 \\
0 \\
0 \\
33 \\
50 \\
0 \\
0\end{array}$ \\
\hline & \multicolumn{2}{|c|}{$\begin{array}{c}\mathrm{ns} \\
\mathrm{Zc}=0.337\end{array}$} & \multicolumn{2}{|c|}{ Mean $=16.1$} \\
\hline \multirow[t]{2}{*}{$\begin{array}{l}\text { MYD x MAC } \\
(\# 66)\end{array}$} & $\begin{array}{l}1 \\
2 \\
3 \\
4 \\
5 \\
6 \\
7\end{array}$ & $\begin{array}{c}10 \\
11 \\
10 \\
11 \\
1 \\
1 \\
5\end{array}$ & $\begin{array}{l}1 \\
3 \\
2 \\
2 \\
0 \\
1 \\
1\end{array}$ & $\begin{array}{c}10 \\
27 \\
20 \\
18 \\
0 \\
100 \\
20\end{array}$ \\
\hline & \multicolumn{2}{|c|}{$\begin{array}{c}\mathrm{ns} \\
\mathrm{Zc}=0.495\end{array}$} & \multicolumn{2}{|c|}{ Mean $=27.9$} \\
\hline
\end{tabular}

Table 3. Weight of dehusked nuts from dwarf parents and macapuno nuts from macapuno-bearing D x T hybrids

\begin{tabular}{|c|c|c|}
\hline Sample Number & Weight $(\mathrm{g})$ per nut & Classification \\
\hline MYD x MAC & & Type I \\
$52-1$ & 578 & Type I \\
$52-2$ & 1067 & Type I \\
MYD x MAC & & Type I \\
$61-1$ & 773 & Type I \\
$61-2$ & 1271 & \\
$61-3$ & 1320 & Type I \\
MYD x MAC & & Type I \\
$66-1$ & 660 & Type I \\
$66-2$ & 785 & Type I \\
$66-3$ & 584 & Type I \\
$66-4$ & 575 & \\
$66-9$ & 885 & \\
MYD & $502-562$ & \\
MRD & $484-601$ & \\
& & \\
\hline
\end{tabular}




\section{REFERENCES}

ANDRIANO, F.T. and MANAHAN, M. 1937. The nutritive value of green, ripe sport coconut (buko, niyog and macapuno). Phil. Agri. 20:195-198

BALINGASA, E.N. 1975 (Coconut floral biology and flowering habits of some dwarf populations. In Proceedings of the Nat. Coconut Res. Symposium Tacloban City. Nov. 17-19, 1975. pp. 54-76

PCRDF, 1985. Makapuno embryo culture. In PCRDF the first decade 1975-1985 Quezon City pp. $115-117$ 